\title{
Solubility of Isolated Soy Protein in Ionic Environments and an Approach to Improve Its Profile
}

\author{
Tadayasu FuruKawa and Shigenori OHTA \\ Tokyo Research Laboratory, Kyowa Hakko Kogyo Co., Ltd., \\ 3-6-6 Asahi-machi, Machida-shi, Tokyo 194, Japan
}

Received August 9, 1982

\begin{abstract}
The solubility characteristics of isolated soy protein (ISP) in high ionic environments were measured in accordance with an NSI (nitrogen solubility index) method in order to study the effect of the thermal process in its commercial production. When the acid precipitated protein (APP) dispersions were heated to above $60^{\circ} \mathrm{C}$ and subsequently spray dried, the solubility of the resultant ISP in $0.5 \mathrm{M}$ (molar) $\mathrm{NaCl}$ was lowered with increasing temperature, ranging from $91 \%$ at $60^{\circ} \mathrm{C}$ to $43 \%$ at $90^{\circ} \mathrm{C}$, while the solubility in $\mathrm{H}_{2} \mathrm{O}$ remained at almost the $100 \%$ level regardless of heating condition. Solubility changes in $90^{\circ} \mathrm{C}$-heated ISP in various $0.5 \mathrm{~m}$ (molal) salt solutions indicated that salting-out of this protein preparation can be represented as a function of molal surface tension increment of the salt used; the solubility of ISP in ionic environments can be determined by its hydrophobicity, which seems to increase with a rise in the heat treatment temperature of APP. Therefore, there was a significant difference in salting-out behavior depending upon the order of addition of ingredients to the system; when salt was added to the slurry after the ISP was thoroughly rehydrated, no salting-out was observed in $0.5 \mathrm{~m}$ ionic environments. Ultrasonication of $90^{\circ} \mathrm{C}$-heated APP prior to spray drying was tested to examine the possibility of improving the solubility profiles of resultant ISP, with the result that a remarkable increase of solubility in $0.5 \mathrm{~m}$ $\mathrm{NaCl}$ was attained. The effect of such ultrasonication was probably due to its ability to increase the hydrophilic nature of proteins.
\end{abstract}

The solubility characteristics of food proteins are deeply implicated in their actual and potential applications, since many of the important functional properties relate to waterprotein interactions. Consequently, the nitrogen solubility index (NSI) is used as a practical guide to protein functionality. The solubility profile of proteins in a variety of ionic environments is also a useful index for the prediction of their use, because salts are frequently essential components in many food systems. However, commercially isolated soy protein (ISP), the most commonly used protein material, has been reported to show poor solubility in high ionic environments, ${ }^{1,2)}$ which restricts its uses in foods with a relatively high salt content. In order to release such a restriction, the establishment of a process for obtaining the ISP with a favorable solubility profile in high ionic environments is being keenly sought after. ISPs are produced com- mercially from defatted soy flakes by aqueous extraction, precipitation, neutralization, pasteurization by heat, and subsequent spray drying. ${ }^{3)}$ Such methods of preparation affect the molecular structure of proteins, and when a thermal process is involved, globular proteins such as soy proteins are transformed into new molecules with an increased hydrophobic region. ${ }^{4,5)}$ This increase in hydrophobicity may give a lower solubility to ISP under the condition of higher surface tension caused by salt. From these considerations, the attenuation of its hydrophobicity, or the increase of its hydrophilic nature, may well improve the solubility characteristics of ISP in a high ionic environment.

The phenomenon of ultrasonic-induced dissociation of heat-treated soy protein has already been reported, in which the depolymerization of protein aggregates was suggested to be caused by the partial cleavage of intermo- 
lecular hydrophobic bondings accompanying exposure of the hydrophilic region. ${ }^{6}$ In this study, firstly, the solubilities of ISPs prepared by spray drying the acid precipitated protein (APP) after heat treatment at various temperatures were measured to evaluate the effect of the thermal process in ISP production on the solubility characteristics of ISP. Secondly, the structural or bonding factors responsible for the reduced solubility of ISP in high ionic environments were examined, and then ultrasonication of heat-treated APP prior to spray drying was tested as a method for the improvement of its solubility characteristics.

\section{MATERIALS AND METHODS}

1) Isolated soy protein. Isolated soy protein (ISP) was prepared by spray drying the acid precipitated protein (APP) dispersions after heat treatment. APP was obtained as previously reported, $\left.{ }^{6}\right)$ using aqueous extraction of the defatted soy flakes (Nihon Koyu Co., Ltd.; NSI ${ }^{7)}$ 87.5) at pH 7.5 (ratio of flakes to water, $1: 15$ ), clarifying the extract by centrifugation, and subsequently washing the protein precipitates with water. The aqueous dispersions $(10.0 \%$ protein) of the resultant APP were prepared on a weight basis adjusting the $\mathrm{pH}$ to 7.0 with $\mathrm{NaOH}$, where the protein content was determined by the biuret method. ${ }^{8)}$ Heat treatment of the APP dispersions was carried out at various temperatures up to $90^{\circ} \mathrm{C}$ for $30 \mathrm{sec}$ by steam injection, as described previously. ${ }^{6)}$ The ISP obtained had the following analysis: moisture, $4.5 \%$; protein(nitrogen $\times$ $6.25), 89.1 \%$; ash, $4.5 \%$.

2) Measurement of solubility. The AOCS NSI method No. Ba $11-65^{7}$ was used with some modifications to evaluate the solubility characteristics of ISP. To $1.00 \mathrm{~g}$ of ISP, $50 \mathrm{ml}$ of $\mathrm{H}_{2} \mathrm{O}$ or salt solution was added and the mixture was equilibrated at $40^{\circ} \mathrm{C}$ for $90 \mathrm{~min}$ in a shaker bath, adjusting the $\mathrm{pH}$ to 6.50 with $\mathrm{HCl}$ or $\mathrm{NaOH}$ in order to avoid its effect during the solubilization process. The resulting slurry was centrifuged at $1,000 \times g$ for $10 \mathrm{~min}$ and the nitrogen in the supernatant, which was regarded as "soluble," was then determined by a Kjeldahl analysis. The solubility ( $\%$ ) was caluclated as the ratio of the soluble to the total nitrogen in $1.00 \mathrm{~g}$ of ISP sample.

3) Ultrasonication. Prior to spray drying, ultrasonication of the heat-treated APP dispersion was carried out using a Sonicator (Heat System-Ultrasonics, Inc., N.Y., Model W-220F) which delivers a nominal $200 \mathrm{~W}$ of power at a frequency of $20 \mathrm{kHz}$. In a $500 \mathrm{ml}$ beaker, $500 \mathrm{~g}$ of the APP dispersion was sonicated with the flat titanium tip immersed to $2.5 \mathrm{~cm}$ in depth. During sonication the beaker was surrounded by an ice-water mixture to avoid any unfavorable rise in the temperature of the dispersion.

\section{RESULTS AND DISCUSSION}

\section{Effect of thermal process on solubility pro-} file of ISP

Figure 1 shows the solubility of ISPs prepared by spray drying the APP dispersions after heat treatment at various temperatures. The solubility in $0.5 \mathrm{M} \mathrm{NaCl}$ was dependent upon the heat treatment temperature of APP, while that in $\mathrm{H}_{2} \mathrm{O}$ was independent. The former decreased from $91 \%$ at $60^{\circ} \mathrm{C}$ to $43 \%$ at $90^{\circ} \mathrm{C}$ and was constant above the $90 \%$ level with heating to below $60^{\circ} \mathrm{C}$, whereas the latter remained at almost the $100 \%$ level regardless of heating condition. The commercial process for ISP production frequently involves the heat treatment of APP above $70^{\circ} \mathrm{C}$ for pasteurization, with the result that the product is unfavorably damaged in its solubility characteristics as mentioned above. In this respect, Shen refers to the considerable insolubilization

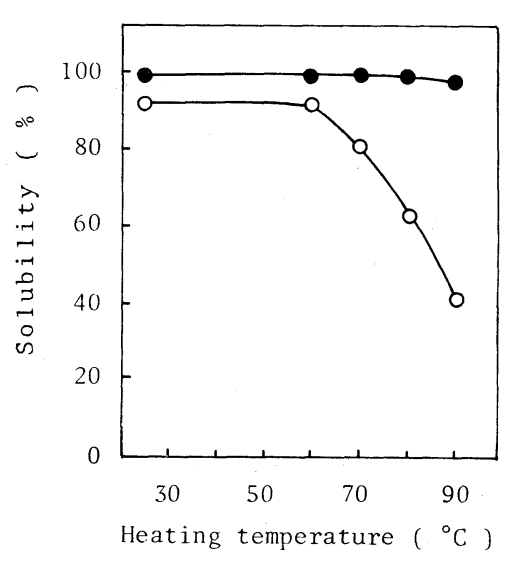

FIG. 1. Effect of the APP Dispersion Heat Treatment on the Solubility of Resultant ISP.

Prior to spray drying, the APP dispersions (10\% protein) were heated at the indicated temperatures for $30 \mathrm{sec}$ by steam injection (see MATERIALS AND METHODS), where the $25^{\circ} \mathrm{C}$-treatment means virtually no heating. The solubility of the resultant ISPs was measured by the NSI method ${ }^{8)}$ with some modifications; to $1.00 \mathrm{~g}$ of ISP, $50 \mathrm{ml}$ of $\mathrm{H}_{2} \mathrm{O}$ (O) or $0.5 \mathrm{M} \mathrm{NaCl}(\bigcirc)$ was added, the mixture was shaken at $40^{\circ} \mathrm{C}$ for $90 \mathrm{~min}$ and subsequently centrifuged at $1,000 \times g$ for $10 \mathrm{~min}$. The solubility is represented as the ratio of the soluble to the total nitrogen in the sample. 
of proteins in $0.5 \mathrm{M}$ ionic environments due to commercial processing. ${ }^{2)}$ The inferior solubility gives poor functional properties, because many of them are related to the interaction of proteins with water. In practice, ISP can be expected to be applied to many foods in the presence of $\mathrm{NaCl}$ such as meat and fish paste products. A $0.5 \mathrm{M}$ concentration of $\mathrm{NaCl}$ is so common that the above mentioned solubility profile must be considered as a serious handicap for commercial ISP in its food applications.

With respect to the heat treatment of APP, it has previously been reported that the degree of aggregate formation as a practical index of thermally induced denaturation of soy proteins increased progressively as the heating temperature was raised above $70^{\circ} \mathrm{C},{ }^{11)}$ inversely corresponding to the solubility profile of ISP in $0.5 \mathrm{M} \mathrm{NaCl}$ observed here (Fig. 1); the process of denaturation caused stronger suppression of the solubility of proteins in a high ionic environment. This suggests that the structural or bonding changes of protein produced during the heat treatment process of APP may be responsible for such a variation in the solubility characteristics of resultant ISP.

\section{Solubility changes of ISP in various ionic environments}

In order to examine the protein-salt interaction in detail during the solubilization process of ISPs and then to discuss their structural or bonding factors, the solubility in various ionic environments was measured with the following two representative samples: nonheated (NH)-ISP as the native type and $90^{\circ} \mathrm{C}$ ISP as the fully denatured type. These were prepared by spray drying the APP dispersions after no heating and $90^{\circ} \mathrm{C}$ heating, respectively, as described in the legend to Fig. 1.

Figure 2 shows the effect of $\mathrm{NaCl}$ on the solubility of the ISP samples. The profile of $90^{\circ} \mathrm{C}$-ISP was dramatically different from that of NH-ISP. With increasing $\mathrm{NaCl}$ concentration, the solubilization of $90^{\circ} \mathrm{C}$-ISP was suppressed; the solubility decreased from $93 \%$ in $\mathrm{H}_{2} \mathrm{O}(0 \mathrm{M})$ to $39 \%$ in a $1.0 \mathrm{M}$ ionic environ-

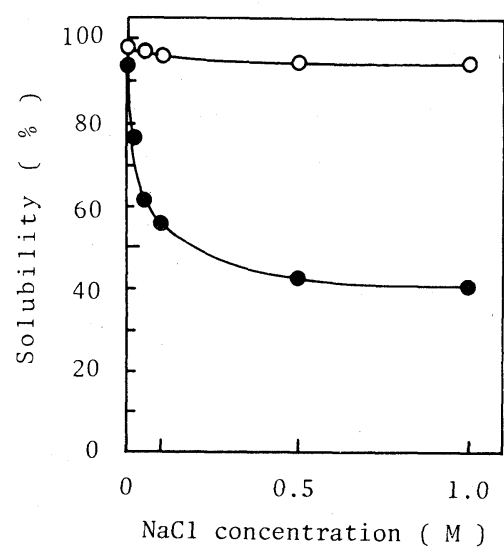

FIG. 2. Effect of $\mathrm{NaCl}$ on the Solubility of ISP.

$\mathrm{NH}-(\mathrm{O})$ and $90^{\circ} \mathrm{C}$-ISP (O) preparations were used, which were prepared by spray drying APP dispersions $\left(10 \%\right.$ protein) after no heating and $90^{\circ} \mathrm{C}$-heating, respectively, as shown in Fig. 1. The solubility of these ISPs in $\mathrm{NaCl}$ solutions of various concentrations was measured by the same method as in Fig. 1 .

ment, leveling off at $0.5 \mathrm{M}$. Conversely, NHISP, which seemed to be still in its native form, underwent no salting-out. However, the salting-in effect of $\mathrm{NaCl}$ should also be taken into consideration with this solubility phenomenon. As a result, the solubility vs. $\mathrm{NaCl}$ concentration curve shown in Fig. 2 is considered to reflect the complex interaction between salting-out and salting-in, although the effect of the former is predominant. Saltingout is based upon the hydrophobic interaction between proteins and salt, while salting-in is a nonspecific electrostatic interaction between charged protein molecules and the ionic environment. The property of a salt that affects its hydrophobic interaction is quantified by the molal surface tension increment, and forms the basis of a natural lyotropic series. On the other hand, salting-in is not dependent on the type of ion but on the ionic strength. In subsequent experiments, the solubility of ISP was measured at a $0.5 \mathrm{~m}$ (molal) concentration using $\mathrm{NaNO}_{3}, \quad \mathrm{NaBr}, \quad \mathrm{NaCl}, \mathrm{Na}_{2} \mathrm{HPO}_{4}, \quad$ and $\mathrm{Na}_{2} \mathrm{SO}_{4}{ }^{9}{ }^{9}$ As shown in Fig. 3, the salting-out of $90^{\circ} \mathrm{C}$-ISP in a variety of $0.5 \mathrm{~m}$ sodium salts appears to correspond favorably with their molal surface tension increment, being independent of their ionic strength and following 


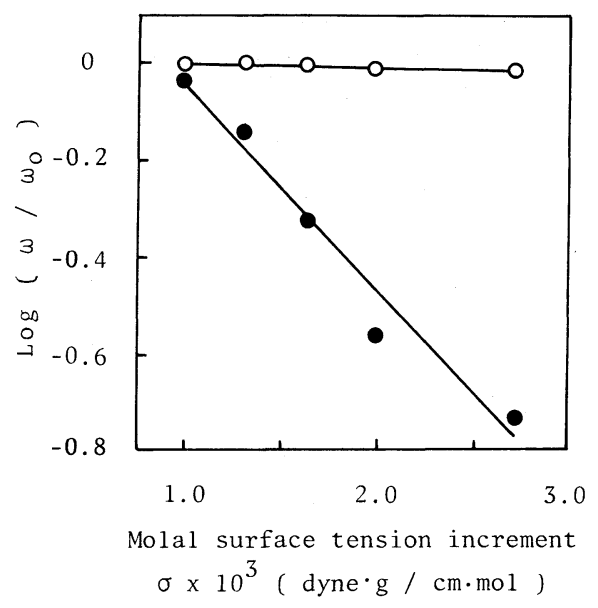

FIG. 3. Solubility of ISP as a Function of Molal Surface Tension Increment of Various Salts.

The NH- (O) and $90^{\circ} \mathrm{C}$-ISP (O), which were prepared as described in Fig. 2, were solubilized in $\mathrm{H}_{2} \mathrm{O}$ and $0.5 \mathrm{~m}$ (molal) solutions of various salts, having the following values of molal surface tension increment $(\sigma): \mathrm{NaNO}_{3}$, 1.06; NaBr, 1.32; NaCl, 1.64; $\mathrm{Na}_{2} \mathrm{HPO}_{4}, 2.02 ; \mathrm{Na}_{2} \mathrm{SO}_{4}$, $2.73\left(\times 10^{3} \mathrm{dyn} \cdot \mathrm{g} / \mathrm{cm} \cdot \mathrm{mol}\right){ }^{9}{ }^{9}$ The method of solubility measurement was the same as in Fig. 1 and the solubilities in $\mathrm{H}_{2} \mathrm{O}\left(\omega_{0}\right)$ and in ionic environments $(\omega)$ are calculated.

the lyotropic or Hofmeister series of effectiveness for the salts. This experimental observation suggests that the solubility of the ISP in these ionic environments is determined predominantly by the hydrophobic interaction between proteins and salt, and little by their electrostatic interaction. No salting-out took place for NH-ISP regardless of surface tension increment. The result obtained here means that $90^{\circ} \mathrm{C}$-ISP has a disadvantage at hydration with the competition of the salts for available water in comparison with NH-ISP; $90^{\circ} \mathrm{C}$-ISP is more hydrophobic than NH-ISP.

Changes in the molecular conformation of APP during the thermal process involve exposure of the hydrophobic region followed by a rearrangement of the disulfide bonded region. $^{4,5)}$ Such structural alteration could not be fully restored by a disulfide bond-reducing agent alone, but also requires an intermolecular hydrophobic bond-cleaving agent such as concentrated urea. In fact, when $90^{\circ} \mathrm{C}$-ISP was dispersed into $0.5 \mathrm{M} \mathrm{NaCl}$ containing $6 \mathrm{M}$ urea, or $6 \mathrm{M}$ urea and $0.01 \mathrm{M}$ 2-mercapto- ethanol, 93 and $96 \%$ of the proteins were solubilized, respectively. The solubility remained at $61 \%$ in $0.5 \mathrm{M} \mathrm{NaCl}$ containing $0.01 \mathrm{M}$ 2-mercaptoethanol alone. This result also suggests that the lower solubility of denatured soy proteins in high ionic environments can be attributed to their increased hydrophobicity.

This interpretation has been drawn from the solubility measurement of powdered protein in a salt solution. Another relationship may be found between fully hydrated proteins and salts. These was, as expected, a significant difference in salting-out behavior depending on the order of addition of ingredients to the system. When salt was added to the slurry after the ISP had been thoroughly dispersed, salting-out was not observed in each $0.5 \mathrm{~m}$ ionic environment mentioned above (data not shown). Lah and Cheryan have also found the same effect from the order of addition of $\mathrm{NaCl}$ on protein dispersibility for an ultrafiltered full-fat soybean product. $^{10)}$ In food applications, ISP is frequently added in high ionic environments in the form of powder. Therefore an improvement in the solubility of ISP in a powder-salt solution system is still important at the present time.

\section{An approach to improve the solubility char- acteristics of ISP}

The above mentioned results suggest that an improvement in the solubility characteristics of $90^{\circ} \mathrm{C}$-ISP could be attained by making it more hydrophilic or less hydrophobic. Ultrasonication has been reported to be definitely effective in modifying the flow behavior of heat-treated APP dispersions, where the ultrasound energy acts to physically dissociate the protein aggregates into new molecules with an increased hydrophilic nature. ${ }^{6}$ ) Therefore ultrasonication can be expected to be a useful tool for obtaining ISP with improved solubility characteristics in high ionic environments. Figure 4 shows the effect of ultrasonication of heat-treated APP on the solubility of resultant ISP. In this experiment, each $500 \mathrm{~g}$ of APP dispersion ( $10.0 \%$ protein) was heated in advance at $90^{\circ} \mathrm{C}$ for $30 \mathrm{sec}$ and was then 


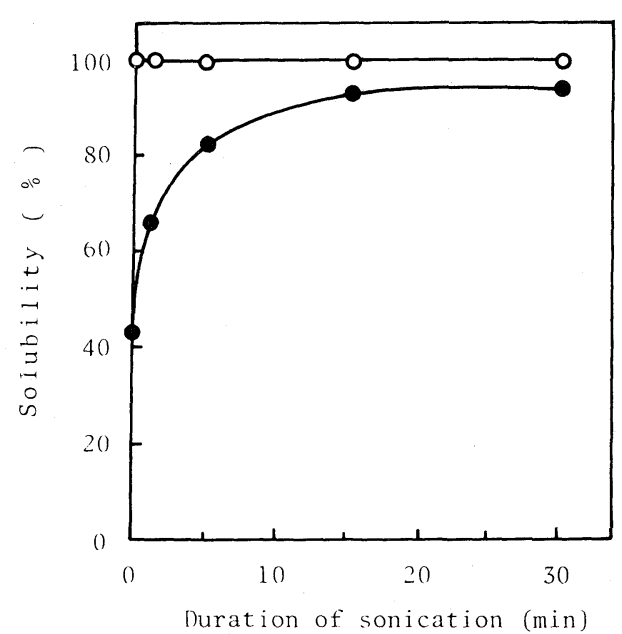

FIG. 4. Effect of Ultrasonication of APP Dispersions on the Solubility Profile of Resultant ISP.

The APP dispersion ( $10 \%$ protein) was heated at $90^{\circ} \mathrm{C}$ for $30 \mathrm{sec}$ by steam injection and then ultrasonicated at $200 \mathrm{~W} / 500 \mathrm{~g}$ for the indicated period, followed by spray drying. The solubilities of resultant ISPs in $\mathrm{H}_{2} \mathrm{O}(\mathrm{O})$ and $0.5 \mathrm{M} \mathrm{NaCl}$ ( ) were measured by the same method as in Fig. 1.

treated under a $200 \mathrm{~W}$ ultrasonic power field, followed by spray drying. As expected, a rapid increase of solubility in $0.5 \mathrm{M} \mathrm{NaCl}$ from $43 \%$ to $93 \%$ was observed during the initial $15 \mathrm{~min}$ irradiation, and then a gradual increase with prolonged treatment, while the solubility in $\mathrm{H}_{2} \mathrm{O}$ was kept at almost the $100 \%$ level regardless of ultrasonication. With respect to factors other than the sonication duration, the higher the ratio of ultrasound power/protein dispersion ("power density"), the higher the solubility of resultant ISP in the salt solution (data not shown).

Ultrasonication has been widely used for solubilizing animal and plant tissue components with its cavitation effect, and has additionally been confirmed to modify the flow properties of protein dispersions so as to improve the efficiency of further treatment processes. $\left.{ }^{6}\right)$ This mechanical treatment is satisfactory in the ISP production line, providing a significant improvement in both the solubility and productivity of the resulting product. However, the significance of the effect is dependent upon the final food system in which the ISP is used. Ultrasonic-treated ISP appears more suitable for application with meat and fish paste products which are relatively high in salt content, although other food ingredients may further modify the functional properties observed in the present model system. composed of ISP, salt, and water.

\section{REFERENCES}

1) A. M. Nash and W. J. Wolf, Cereal Chem.44, 183 (1967).

2) J. L. Shen, J. Agric. Food Chem., 24, 784 (1976).

3) L. P. Hanson, "Vegetable Protein Processing," NOYES DATA Corp. Park Ridge, N. J., 1974, p. 107.

4) W. J. Wolf and T. Tamura, Cereal Chem., 46, 331 (1969).

5) S. Takagi, N. Okamoto, M. Akashi and K. Yasumatsu, Nippon Shokuhin Kogyo Gakkaishi, 26, 139 (1979).

6) T. Furukawa and S. Ohta, Agric. Biol. Chem., 47, 745 (1983).

7) AOCS, "Official and Tentative Method of American Oil Chemists Society," 3rd Ed., American Oil Chemists Society, Chicago, IL., 1970.

8) E. Layne, "Method in Enzymology," Vol. III, ed. by S. P. Colowick and N. O. Kaplan, Academic Press Inc., New York, N. Y., 1957, p. 450.

9) W. Melander and C. Horvath, Arch. Biochem. Biophys., 183, 200 (1977).

10) C. L. Lah and M. Cheryan, J. Agric. Food Chem., 28, 911 (1980).

11) T. Furukawa and S. Ohta, Nippon Shokuhin Kogyo Gakkaishi, 28, 451 (1981). 